\title{
A new species of Curculionichthys (Siluriformes: Loricariidae) from the north edge of the Brazilian Shield, lower Amazon basin
}

\author{
Suelen P. Gamarra ${ }^{1}$, Bárbara B. Calegari ${ }^{1,2}$ and Roberto E. Reis ${ }^{1}$
}

A new species of Curculionichthys is described from the rio Curuá-Una basin, in the northern edge of the Brazilian Shield, State of Pará, Brazil. The new species is diagnosed from congeners by possessing a single rostral plate, by having darkened tooth-crowns, and by a series of morphometric and meristic data. A close examination of the species of Curculionichthys revealed the presence of hyperthrophied odontodes on both dorsal and ventral margins of the snout tip, which are illustrated by electronic microscopy. A discussion is provided on possible phylogenetic relationships of the new taxon. The new species is provisionally accessed as Least Concern (not threatened).

Keywords: Cascudinho, Fishes, Neotropical, Systematics, Taxonomy.

Uma nova espécie de Curculionichthys é descrita da bacia do rio Curuá-Una, na borda norte do Escudo Brasileiro, Estado do Pará, Brasil. A nova espécie é diagnosticada de seus congêneres por possuir uma placa rostral única, a coroa dos dentes escurecida e por uma séria de dados morfométricos e merísticos. Um exame detalhado das espécies de Curculionichthys revelou a presença de odontódeos hipertrofiados nas margens dorsal e ventral da ponta do focinho, que são ilustrados por microscopia eletrônica. Uma discussão é apresentada sobre as possíveis relações filogenéticas do novo táxon. A nova espécie é provisoriamente categorizada como Menos Preocupante (não ameaçada).

Palavras-chave: Cascudinho, Neotropical, Peixes, Sistemática, Taxonomia.

\section{Introduction}

Curculionichthys is a genus of Hypoptopomatinae recently described by Roxo et al. (2015), based on a molecular phylogeny and diagnosed by the following combination of characters: (1) a pair of rostral plates at the tip of the snout; (2) two large pre-nasal plates just posterior to the rostral plates; (3) a supra-opercular plate that receives the laterosensory canal from the compound pterotic before the preopercle; (4) a well-developed membrane at the anal opening in females; and (5) a V-shaped dorsal-fin spinelet. The subsequent year, Silva et al. (2016) redefined the genus, amending the above diagnosis with two additional features: (6) a dark blotch of pigmentation covering the caudal peduncle that extends onto median caudal-fin rays; and (7) snout tip lacking hypertrophied odontodes.

Curculionichthys consists of 13 nominal species (Calegari et al., 2018; Fricke et al., 2019), which are distributed on the southeastern Guiana Shield and in the central and northern portions of the Brazilian Shield, in the upper São Francisco, upper Paraná, and upper Paraguay rivers, as well as in the Amazon tributaries Tocantins, Xingu, Tapajós, and eastern lower Madeira. In a recent expedition of the Aquatic Faunal
Survey of the Lower Amazon Project, a new species of Curculionichthys was discovered in the rio Curuá-Una basin, in the northern edge of the Brazilian Shield, State of Pará, Brazil, which is herein described.

\section{Material and Methods}

Terminology and counts of dermal plates are according to Schaefer (1997). Morphological measurements were taken point-to-point to the nearest $0.1 \mathrm{~mm}$ with digital calipers according to Carvalho, Reis (2009) with the modifications introduced by Calegari et al. (2011, 2014) and expressed as percent of standard length (SL) or head length (HL). All measurements and counts were performed under a stereomicroscope for both the new species and comparative material (listed in Calegari et al., 2018) for the diagnostic comparisons. Data for Curculionichthys paresi Roxo, Zawadzki, Troy, 2014 and C. jumaorum Dias, Silva, Oliveira, Roxo, 2018 were obtained from original descriptions. Vertebral counts comprise all vertebral centra, including the five centra of the Weberian apparatus, and the caudal complex centrum (PU1+U1) counted as a single element. The osteological examination was conducted on

${ }^{1}$ Laboratório de Sistemática de Vertebrados, Pontifícia Universidade Católica do Rio Grande do Sul, Av. Ipiranga, 6681, 90619-900 Porto Alegre, RS, Brazil. (SPG) suelengamarra@gmail.com, Dhttps://orcid.org/0000-0001-7810-0843; (BBC) barbara.calegari@gmail.com, OChttps://orcid.org/0000-0001-6335-6854; (RER) reis@pucrs.br, Dhttps://orcid.org/0000-0003-3746-6894 (corresponding author).

${ }^{2}$ Department of Vertebrate Zoology, National Museum of Natural History, Smithsonian Institution, Washington, DC 20560,USA. 
specimens cleared and double-stained (cs) for bone and cartilage according to the technique described by Taylor, Van Dyke (1985). High-resolution surface imaging of the snout was obtained from Field Emission Scanning Electron Microscopy (FESEM) performed in a FEI Inspect F50 equipment in the Central Laboratory for Microscopy and Microanalysis of the Pontifícia Universidade Católica do Rio Grande do Sul.

GenSeq nomenclature follows Chakrabarty et al. (2013). Total genomic DNA was isolated through the DNeasy Blood \& Tissue Kit (QIAGEN). The polymerase chain reaction (PCR) of the mitochondrial gene Cytochrome oxidase I ( $\mathrm{col}$ ) was performed in $25 \mu \mathrm{l}$ of 10 $\mathrm{mM}$ of each primer LCO1490 and HCO2198 (Folmer et al., 1994), 1 x Master Mix Kit (QIAGEN), and $40 \mathrm{ng}$ of DNA. The fragment was amplified under the following thermocycler conditions: initial denaturation of $3 \mathrm{~min}$ at $96^{\circ} \mathrm{C}, 35$ cycles of $60 \mathrm{~s}$ at $95^{\circ} \mathrm{C}$, touchdown annealing for $20 \mathrm{~s}$ at each temperature $48^{\circ} \mathrm{C}, 46^{\circ} \mathrm{C}, 44^{\circ} \mathrm{C}, 42^{\circ} \mathrm{C}$, and $2 \mathrm{~min}$ at $72^{\circ} \mathrm{C}$; followed by a final extension of $5 \mathrm{~min}$ at $72^{\circ} \mathrm{C}$. The amplicon was purified and sequenced in both directions at the Functional Biosciences, Madison, USA.

The geographic distribution map was prepared with the QGIS software (v. 2.14.5) using the tutorial of Calegari, Fontenelle (2017). Institutional abbreviations are those listed at http://www.asih.org/codons.pdf (Sabaj, 2016).

\section{Results}

\section{Curculionichthys hera, new species}

urn:1sid:zoobank.org:act:ABBB1465-4147-4B90-A15D7E17A64D33B5

\section{Figs. 1-3; Tab. 1}

Holotype. MCP 52500, female, $25.1 \mathrm{~mm}$ SL, igarapé do Onça, tributary to rio Curuá-Una on road BR-163 between Belterra and Rurópolis, Belterra, Pará, Brazil, 3³3’35.3”S 54 52'09.2”'W, elevation $80 \mathrm{~m}$ asl, 19 October 2016, R. E. Reis, B. B. Calegari, T. P. Carvalho, J. de Bogotá, C. Oliveira, J. Souza, and E. Cerdeira.

Paratypes. Brazil, Pará, rio Amazonas basin: MCP 51571, 70, 14.6-25.5 mm SL + 2 cs, 24.0-25.6 mm SL + 9 tissue samples; NUP 20539, 7, 18.8-22.7 mm SL; AMNH 267150, 7, 18.1-23.3 mm SL; MZUSP 123948, 7, 18.6-24.5 mm SL; all collected with the holotype. MCP 51600, 15, 15.8-24.2 $\mathrm{mm}$ SL +4 tissue samples, igarapé Moju, tributary to rio Curuá-Una on road BR-163 between Belterra and Rurópolis, Belterra, 325'05.8'S 54'54'46.7'W, elevation $67 \mathrm{~m}$ asl, 19 October 2016, R. E. Reis, B. B. Calegari, T. P. Carvalho, J. de Bogotá, C. Oliveira, J. Souza, and E. Cerdeira.

Genseq-2 coI. MCP 51600 (tissue tag 426); GenBank Accession Number MK24168.
Diagnosis. Curculionichthys hera is distinguished from its congeners, except $C$. jumaorum and $C$. karipuna Silva, Roxo, Melo, Oliveira, 2016 by possessing a single rostral plate ( $v s$. a pair of rostral plates); and from congeners except for $C$. jumaorum and C. sabaji Roxo, Silva, Ochoa, Oliveira, 2015 by having darkened tooth-crowns (vs. hyaline to light yellow tipped teeth). The new species is further distinguished from $C$. oliveirai (Roxo, Zawadzki, Troy, 2014), C. sabaji, C. tukana Roxo, Dias, Silva, Oliveira, 2017, and C. luteofrenatus (Britski, Garavello, $2007)$ by the smaller prepelvic distance $(42.0-45.6 \%$ vs. $46.3-46.8 \%, 46.0-48.5 \%, 46.2-47.3 \%$, and $46.1-50.7 \%$ $\mathrm{SL}$, respectively); from the above species and also from $C$. itaim Roxo, Dias, Silva, Oliveira, 2017 and C. jumaorum, by the smaller suborbital distance $(10.3-16.4 \%$ vs. 21.7 $22.8 \%, 18.6-20.0 \%, 19.2-21.2 \%, 17.5-23.4 \%, 17.8-23.2 \%$, and $17.6-22.6 \% \mathrm{HL}$, respectively). The new species also differs from C. coxipone Roxo, Silva, Ochoa, Oliveira, 2015, C. sabaji, C. insperatus (Britski, Garavello, 2003), C. paresi, and C. jumaorum by the number of premaxillary teeth (15-20 vs. 7-15, 7-13, 6-14, 6-10, and 25-30, respectively). Additionally, $C$. hera differs from $C$. coxipone, C. luteofrenatus, C. tukana, C. sagarana Roxo, Silva, Ochoa, Oliveira, 2015, C. insperatus, and C. paresi by possessing fewer plates in the middle series of lateral plates (22-23 vs. 25-27, 25-26, 24-26, 24-25, 24-25, and 24-25, respectively). The new species further differs from C. insperatus, C. sabaji, C. paresi, and C. jumaorum by the number of dentary teeth (12-21 vs. 5-11, 5-12, 4-7, and 20-27, respectively); and from C. coxipone, C. oliveirai, and $C$. paresi by the smaller body depth at the dorsalfin origin $(11.3-15.9 \%$ vs. $16.3-18.5 \%, 17.6-20.3 \%$, and $16.9-20.7 \% \mathrm{SL}$, respectively). It is distinguished from C. sabaji, C. tukana, and C. itaim by a narrower head (52.2-60.9\% vs. 61.8-64.8\%, 66.4-69.0\%, and 61.7-67.6\% respectively); from $C$. coxipone, $C$. oliveirai, $C$. tukana, $C$. luteofrenatus, and $C$. itaim by the smaller distance between pectoral- and pelvic-fin origins (12.5-16.8 vs. 16.9-18.7\%, $17.4-19.7 \%, 18.8-20.4 \%, 16.9-20.6 \%$, and $17.3-23.1 \%$ $\mathrm{SL}$, respectively); from $C$. oliveirai by the shallower caudal peduncle $(5.5-9.2 \%$ vs. $10.4-10.8 \% \mathrm{SL})$; from $C$. jumaorum by having a longer first pelvic-fin unbranched ray (17.2-23.5\% vs. $14.8-15.7 \% \mathrm{SL})$, and from C. karipuna by laking an irregular concentration of chromatophores that entirely cover the anal-fin origin and adjacent region (vs. pigmentation present around the anal-fin origin and adjacent region). The new species is also distinguished by the fewer lateral abdominal plates (4-5 vs. 6-7 in $C$. karipuna and $C$. luteofrenatus, 6-9 in $C$. sagarana and $C$. sabaji, 7-8 in C. tukana, C. scaius Calegari, Gamarra, Reis, 2018, and C. itaim, and 7-9 in C. coxipone). Finally, the new species is distinguished from C. sagarana, C. insperatus, C. coxipone, C. luteofrenatus, C. piracanjuba (Martins, Langeani, 2012), and C. sabaji by having a single series of large plates in middle abdominal series (vs. three regular series of plates or small platelets irregularly arranged). 


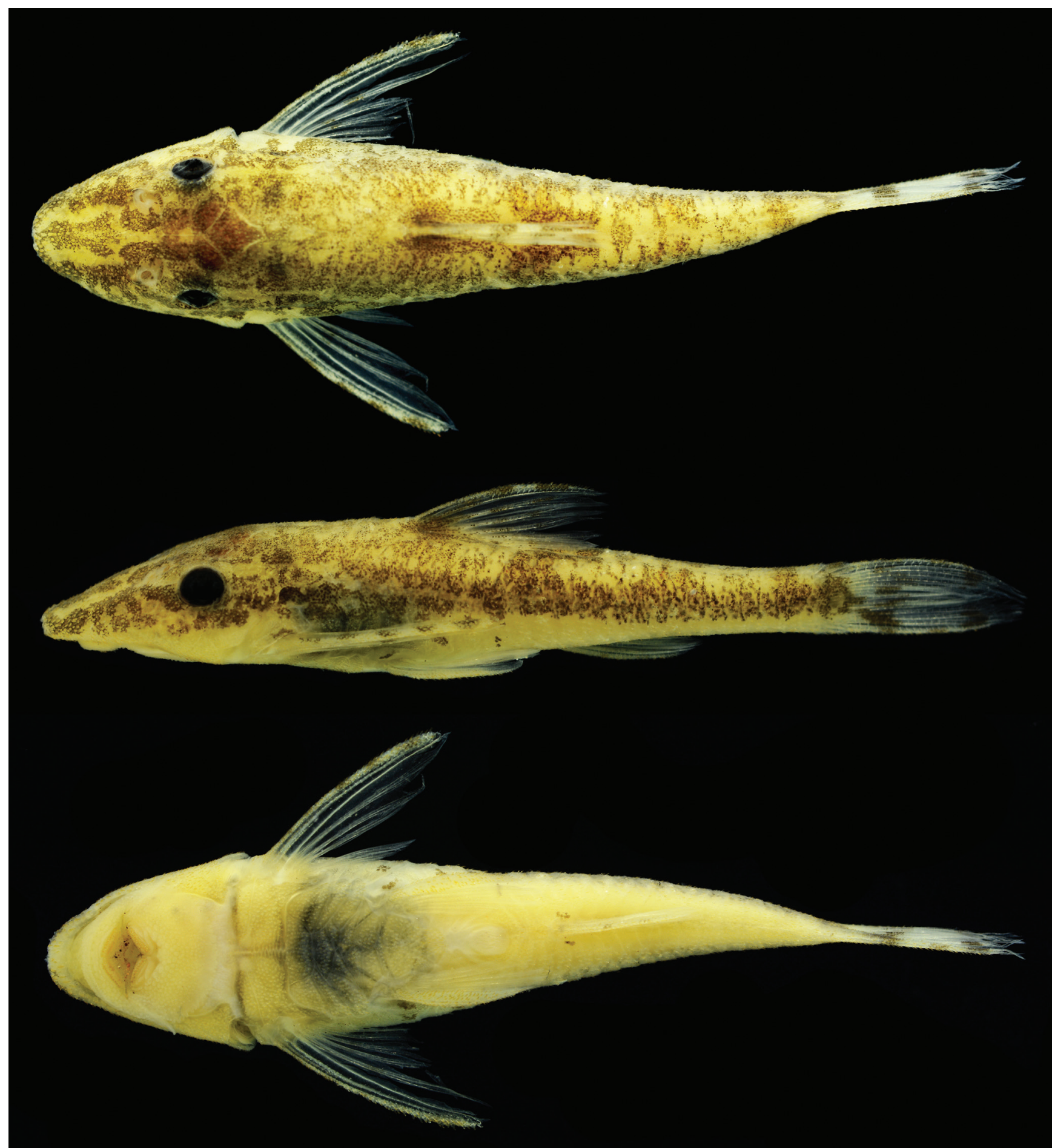

Fig. 1. Curculionichthys hera, holotype, MCP 52500, female, $25.1 \mathrm{~mm}$ SL, igarapé do Onça, tributary to rio Curuá-Una on road BR-163 between Belterra and Rurópolis, Belterra, Pará, Brazil.

Description. Morphometric and meristic data in Tab. 1. Dorsal profile of head straight to slightly concave at anterior snout, concave from that point to middle parietosupraoccipital, and straight to slightly concave from that point to dorsal-fin origin. Head profile triangular in dorsal and ventral perspective with pointed snout. Snout elongated (47.5-56.4\% HL); region anterior to depressed nostrils with slight elevations. Dorsal profile of body sloped and descending from dorsal-fin origin to few plates before end of caudal peduncle. Ventral profile of body relatively straight from snout to caudal-fin origin. Greater body width at opercle or at cleithrum. Body deepest at dorsal-fin origin and shallowest right before end of caudal peduncle. 
Tab. 1. Morphometric and meristic data of Curculionichthys hera based on holotype and 29 paratypes (15 males and 15 females). $\mathrm{SD}=$ standard deviation.

\begin{tabular}{|c|c|c|c|c|c|}
\hline & Holotype & Min & Max & Mean & SD \\
\hline Standard length $(\mathrm{mm})$ & - & 18.7 & 25.7 & 22.0 & \\
\hline Male & - & 18.7 & 20.6 & 19.7 & \\
\hline Female & 25.1 & 21.8 & 25.7 & 24.2 & \\
\hline \multicolumn{6}{|c|}{ Percent of standard length } \\
\hline Head length & 38.0 & 36.8 & 41.4 & 38.7 & 1.2 \\
\hline Predorsal length & 46.0 & 43.6 & 51.2 & 47.1 & 1.7 \\
\hline Postdorsal length & 40.7 & 37.8 & 44.7 & 40.3 & 1.5 \\
\hline Prepectoral length & 29.9 & 27.3 & 33.1 & 29.6 & 1.3 \\
\hline Prepelvic length & 45.3 & 42.0 & 45.6 & 43.9 & 1.0 \\
\hline Preanal length & 64.9 & 60.6 & 68.4 & 64.3 & 2.0 \\
\hline Cleithral width & 24.2 & 21.7 & 27.6 & 23.8 & 1.2 \\
\hline Snout-opercle distance & 29.6 & 28.6 & 33.9 & 30.4 & 1.1 \\
\hline Pectoral-pelvic-fins distance & 16.7 & 12.5 & 16.8 & 15.2 & 1.2 \\
\hline Pelvic-anal-fins distance & 22.3 & 18.6 & 24.4 & 21.4 & 1.5 \\
\hline Dorsal-fin spine length & 24.8 & 21.2 & 27.7 & 24.3 & 1.4 \\
\hline Dorsal-fin base length & 13.1 & 8.3 & 13.9 & 11.4 & 1.2 \\
\hline Pectoral-fin spine length & 26.8 & 24.5 & 31.1 & 27.6 & 1.9 \\
\hline First pelvic-fin unbranched ray length & 18.7 & 17.2 & 23.5 & 19.8 & 1.8 \\
\hline First anal-fin unbranched ray length & 17.7 & 14.5 & 20.7 & 17.6 & 1.5 \\
\hline Caudal-peduncle length & 29.1 & 23.9 & 29.3 & 26.9 & 1.6 \\
\hline Caudal-peduncle depth & 8.2 & 5.5 & 9.1 & 7.6 & 0.9 \\
\hline Caudal-peduncle width & 5.5 & 2.3 & 7.2 & 5.1 & 1.0 \\
\hline Body depth at dorsal-fin origin & 14.7 & 11.3 & 15.9 & 14.0 & 1.1 \\
\hline Body width at dorsal-fin origin & 19.5 & 15.3 & 22.3 & 17.5 & 1.6 \\
\hline \multicolumn{6}{|c|}{ Percent of head length } \\
\hline Head depth & 42.6 & 35.5 & 46.0 & 41.0 & 2.6 \\
\hline Head width & 56.5 & 52.2 & 60.9 & 56.4 & 2.6 \\
\hline Snout length & 53.6 & 47.5 & 56.4 & 51.7 & 2.2 \\
\hline Orbital diameter & 17.3 & 11.7 & 21.4 & 16.0 & 2.3 \\
\hline Interorbital distance & 33.9 & 28.4 & 36.3 & 33.1 & 2.0 \\
\hline Internareal width & 14.3 & 7.3 & 14.6 & 11.0 & 1.7 \\
\hline Nares diameter & 6.6 & 6.6 & 13.6 & 10.1 & 2.2 \\
\hline Male & - & 10.5 & 13.6 & 12.1 & 0.8 \\
\hline Female & - & 6.6 & 9.9 & 8.1 & 1.0 \\
\hline Prenasal length & 43.2 & 34.4 & 45.8 & 39.0 & 2.8 \\
\hline Suborbital depth & 15.1 & 10.3 & 16.4 & 13.8 & 1.5 \\
\hline Barbel length & 5.8 & 2.8 & 8.5 & 5.5 & 1.4 \\
\hline Counts & Holotype & Low & High & Mode & \\
\hline Rigth premaxillary teeth & 21 & 15 & 22 & 21 & \\
\hline Left premaxillary teeth & 20 & 15 & 21 & 20 & \\
\hline Rigth dentary teeth & 20 & 14 & 21 & 20 & \\
\hline Left dentary teeth & 19 & 12 & 21 & 19 & \\
\hline Plates in median lateral series & 23 & 22 & 23 & 23 & \\
\hline Plates in mid-dorsal series & 8 & 7 & 8 & 8 & \\
\hline Predorsal plates & 2 & 2 & 2 & 2 & \\
\hline Branched pectoral-fin rays & 6 & 5 & 6 & 6 & \\
\hline Branched dorsal-fin rays & 6 & 6 & 7 & 6 & \\
\hline Branched pelvic-fin rays & 5 & 5 & 5 & 5 & \\
\hline Branched anal-fin rays & 5 & 4 & 5 & 5 & \\
\hline Branched caudal-fin rays & 14 & 14 & 14 & 14 & \\
\hline
\end{tabular}

Body covered by plates, except around urogenital opening, lateral to pelvic fin, anterior to upper lip, and between lower lip and pectoral girdle. Median series of lateral plates with 22-23 plates; lateral line almost complete ending one plate anterior to caudal-fin origin. Mid-dorsal series with 6 or 7 plates, not surpassing end of dorsal-fin base. Two regular transverse rows of predorsal plates, in addition to nuchal plate. Abdomen completely covered by large plates. Four or five large plates in lateral abdominal series $(n=32)$. Median series of abdominal plates forming single series of large plates, sometimes paired at posterior portion, preceding single, large preanal plate. All abdominal plates bearing small odontodes. Head and body with odontodes uniform in size and distribution, except ventral and dorsal portion of snout tip with slightly hypertrophied and strongly curved odontodes (Fig. 2). Cleithrum and coracoid entirely exposed on ventral surface and covered with odontodes. Rostral plate single, covering tip of snout both ventral and dorsally.

Eye positioned dorsolaterally. Dorsal margin of orbit slightly elevated. Iris operculum present. Lips rounded and papillose with small fleshy ridge immediately behind dentary. Barbel small and laterally positioned, distal portion free from lip margin. Lower lip not reaching pectoral girdle. Posterior border of lower lip crenulate. Teeth thin, bifid, with large leafshaped medial cusp and small lateral cusp.

Dorsal fin II,7; its origin slightly posterior to vertical through end pelvic-fin base. Dorsal-fin spinelet V-shaped, locking mechanism functional. Pectoral fin I,6; pectoral-fin spine long and somewhat slender. Tip of pectoral-fin spine almost reaching to end of first pelvic-fin ray; approximately of same width along its length. Odontodes on pectoral-fin spine distributed on lateral border of spine and gradually increasing in size towards tip. Pectoral-fin branched rays becoming progressively shorter posteriorly. Pelvic fin i,5; pelvicfin unbranched ray thick and shorter than branched rays. Odontodes on ventral surface of pelvic-fin unbranched ray pointing mesially. Interradial membrane of pelvic fin fringed distally. Anal-fin i,5; its unbranched ray ticker and slightly shorter than remaining branched rays. First unbranched analfin ray covered with odontodes. Caudal fin I, 14,I; emarginate. Total vertebrae 27 ( $2 \mathrm{cs})$.

Color in alcohol. Background color of dorsal and lateral portions of head and trunk light brown or yellowish tan, lateroventral and ventral surfaces light yellow to yellowish white (Fig. 1). Dorsal surface of snout with diverging and then somewhat parallel lighter marks, beginning at snout tip, merging anterior to nostrils, and sometimes continuing between nostrils. Posterior portion of head and predorsal region with scattered dark chromatophores concentrated in inconspicuous blotches and leaving lighter areas. Dark brown lateral stripe from side of snout, crossing eye and ending at end of caudal peduncle, clearly delimiting white ventral coloration. Trunk with four conspicuous dark brown bars, extending transversely from dorsal midline to lateral dark stripe. First bar situated at dorsal-fin origin, second bar immediately posterior 


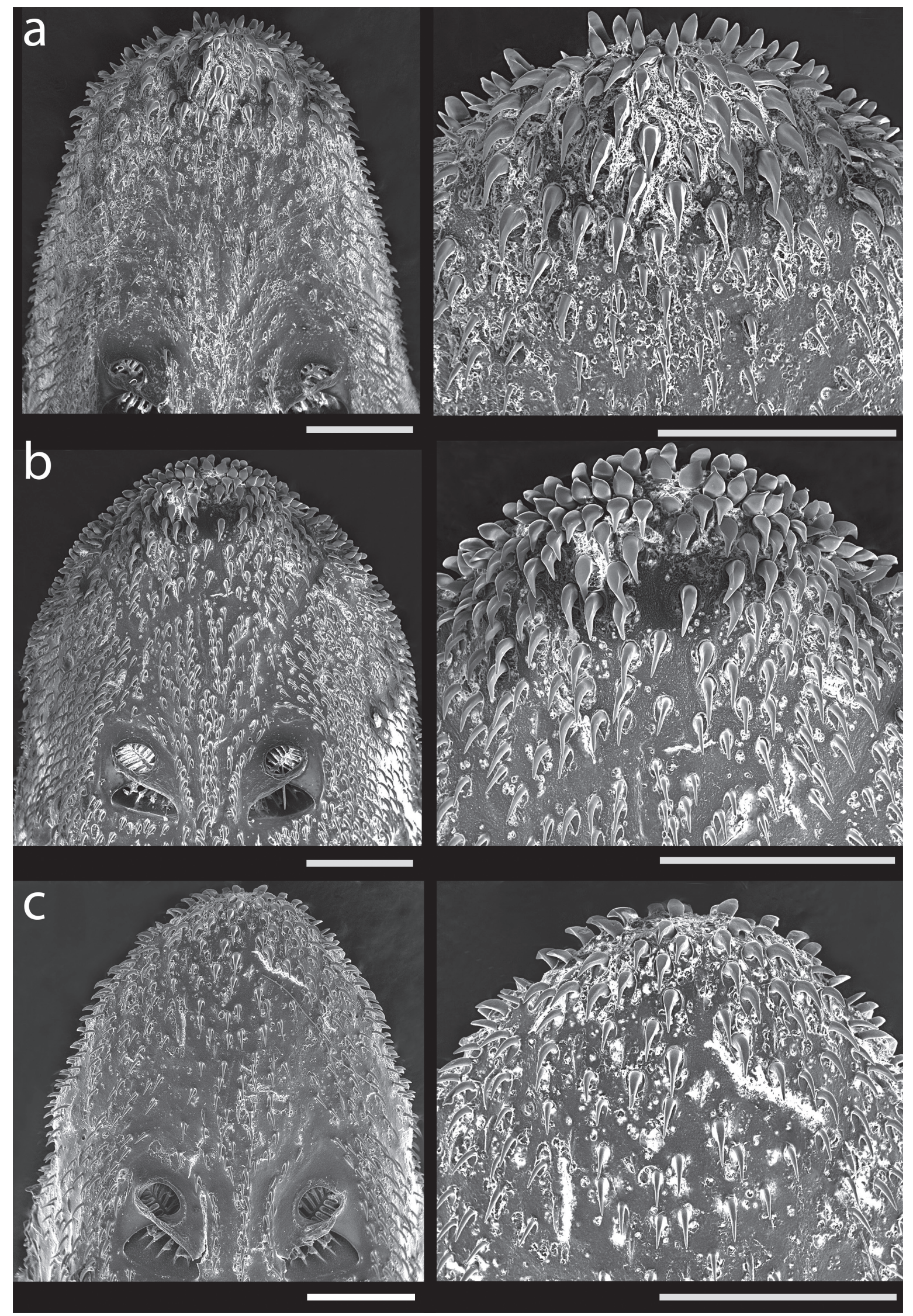

Fig. 2. Field Emission Scanning Electron Microscopy (FESEM) of snout tip showing hypertrophied odontodes of species of Curculionichthys. a. C. hera, paratype, MCP 51571; b. C. itaim, MCP 51569; and c. C. insperatus, MCP 47070. Scale bars $=1 \mathrm{~mm}$. 
to dorsal-fin base and ending near end of depressed dorsal-fin rays. Third dark bar widest, on caudal peduncle immediately posterior to anal-fin base. Fourth bar immediately anterior to caudal fin. Ventral surface mostly unpigmented, except for few inconspicuous dark spots lateral to anal-fin origin. Fins mostly hyaline, with few dark spots. Dorsal-fin spine and branched rays with 2-3 dark brown spots. Pectoral-fin spine with 4-5 inconspicuous dark spots, branched rays hyaline or with fewer and inconspicuous spots. Pelvic fin unpigmented. Anal fin mostly unpigmented but with 2-3 inconspicuous dark dots in unbranched ray. Caudal fin with large, elongated or oblique dark-brown to black blotch at base of central rays, continuous with lateral stripe, and two inconspicuous, transverse dark-brown bands. First band inconspicuous, second band conspicuous, in posterior third of fin, but leaving tips of outermost rays unpigmented. Premaxillary and dentary toothcrown light ochre to golden yellow. Tip of odontodes of first unbranched ray of pectoral, pelvic, and anal fins bright orange.

Sexual dimorphism. As typical of the Hypoptopomatinae, males of Curculionichthys hera possess a conical urogenital papilla posterior to vent, which is absent in females, and a fleshy skin flap on the dorsal margin of the unbranched pelvicfin ray, even in juvenile stage. In addition to that, females are significantly larger than males, with body size of the examined sample ranging from 21.8 to $25.7 \mathrm{~mm} \mathrm{SL}$, while males examined range from 18.7 to $20.6 \mathrm{~mm} \mathrm{SL}$. On the other hand, males show a remarkably secondary sexual dimorphism in the wider naris diameter, 10.5-13.6\% HL (vs. 6.6-9.9\% HL in females; Fig. 3), which is possibly associated with their ability to locate females during the reproductive period.
Distribution. Curculionichthys hera is so far known from the igarapé do Onça and igarapé Moju, two "terra firme" headwater creeks tributaries to the upper rio Curuá-Una, a small river affluent to the Amazon, immediately south of the town of Santarém, Pará State, Brazil, at approximately 60-80 $\mathrm{m}$ asl (Fig. 4).

Habitat and ecology. The type-locality is a mid-size creek with medium water current, clear water, bottom composed of small rocks, gravel, sand, and occasionally mud, with moderate to large amounts of aquatic submerged and marginal vegetation, where the specimens were collected (Fig. 5). A second locality where the species was found has a rocky bed and boulders, but also sandy stretches, and banks covered by forest.

Conservation status. The extinction risk of Curculionichthys hera is provisionally assessed as low despite the limited knowledge of its geographic distribution. The species is so far known from two creeks tributary to the rio Curuá-Una basin, but the basin is illexplored and additional collecting efforts will likely reveal a broader distribution. As the species is naturally abundant and specific threats were not detected, C. hera is tentatively categorized as Least Concern (LC) according to the International Union for Conservation of Nature (IUCN) categories and criteria (IUCN Standards and Petitions Subcommittee, 2017). Additional collecting efforts are worth conducting in the rio Curuá-Una basin in order to better understand the geographic distribution of this species.

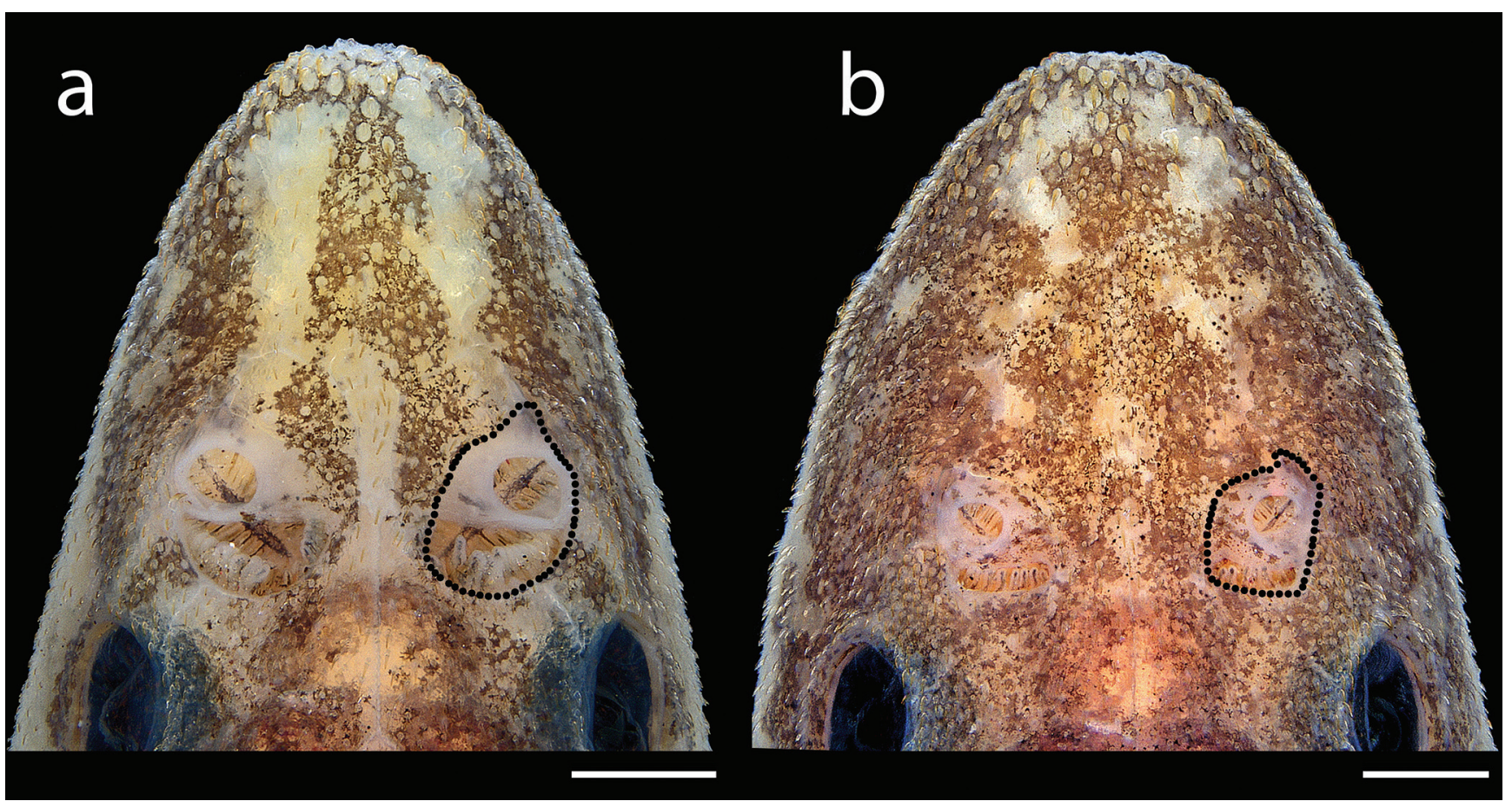

Fig. 3. Snout and sexual dimorphism in size of nares of adults of Curculionichthys hera, MCP 51571, paratypes. a. male; b. female. Scale bars $=1 \mathrm{~mm}$. 


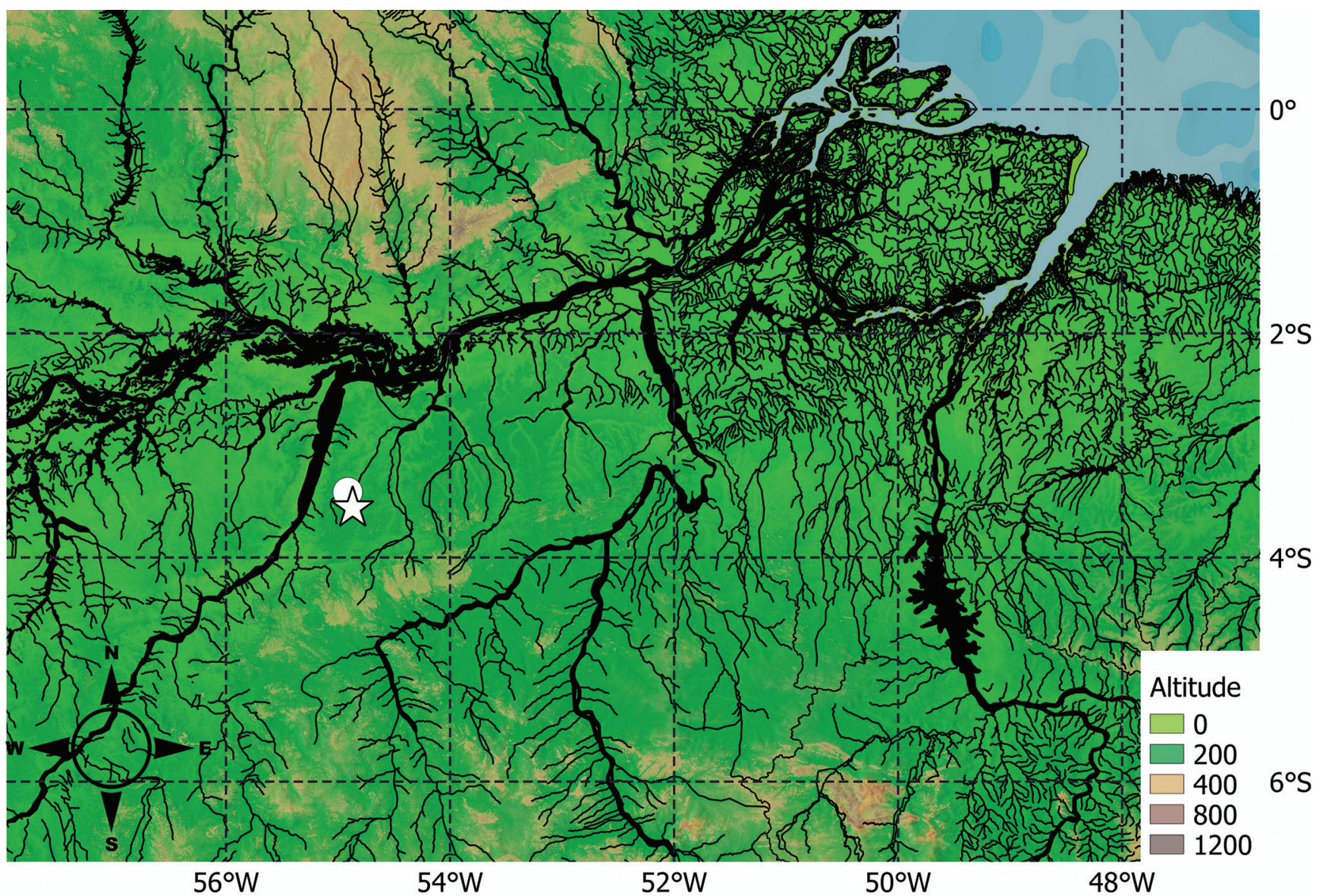

Fig. 4. Collecting localities of Curculionichthys hera in the rio Curuá-Una basin, on road BR-163 between Belterra and Rurópolis, Belterra, Pará, Brazil. Star represents type-locality.

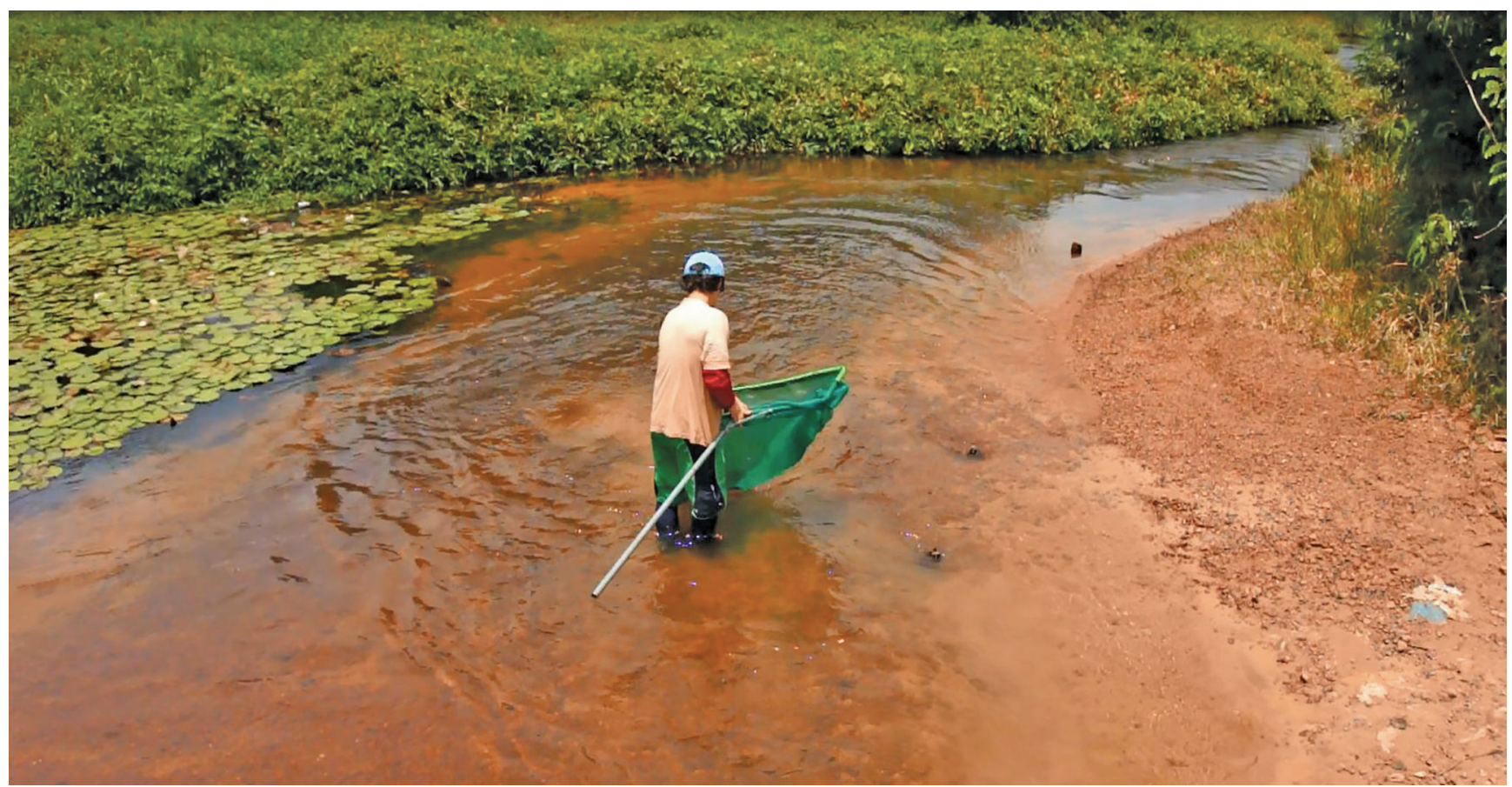

Fig. 5. Type-locality of Curculionichthys hera, igarapé do Onça, tributary to rio Curuá-Una on road BR-163 between Belterra and Rurópolis, Belterra, Pará, Brazil. 
Etymology. Specific epithet hera from the Latin hera, meaning mistress of the house, lady, or queen, in allusion to the larger size of the females relative to males. A noun in apposition.

\section{Discussion}

Curculionichthys is usually regarded as lacking hyperthrophied odontodes on the snout tip, a feature used as diagnostic to the genus (Silva et al., 2016; Roxo et al., 2017). A close examination of most species of Curculionichthys, however, reveals the possession of hyperthrophied odontodes on both upper and lower margins of the snout tip (Fig. 2). Such hyperthrophied odontodes are strongly bent posteriorly and at least twice the length and the width of the remaining odontodes on head, though variation occurs in the level of hypertrophy. Species of typical Hisonotus from southern and southeastern Brazil have even more highly hyperthrophied odontodes on the snout margin and larger body size compared to Curculionichthys, what makes their hyperthrophied odontodes more conspicuous and visible.

Another interesting and useful character that is generally unnoticed or unreported in taxonomic literature is the color of the dentary and premaxillary tooth crown. Most species of Curculionichthys have hyaline to light yellow tooth crowns, but a few species possess cusps light ochre to dark orange, as C. hera, C. jumaorum, and C. sabaji. This feature is a good diagnostic trait and further distinguishes the new species from all Curculionichthys except the two latter species. A darker tooth crown is also present in some other hypoptopomatine species from the Brazilian

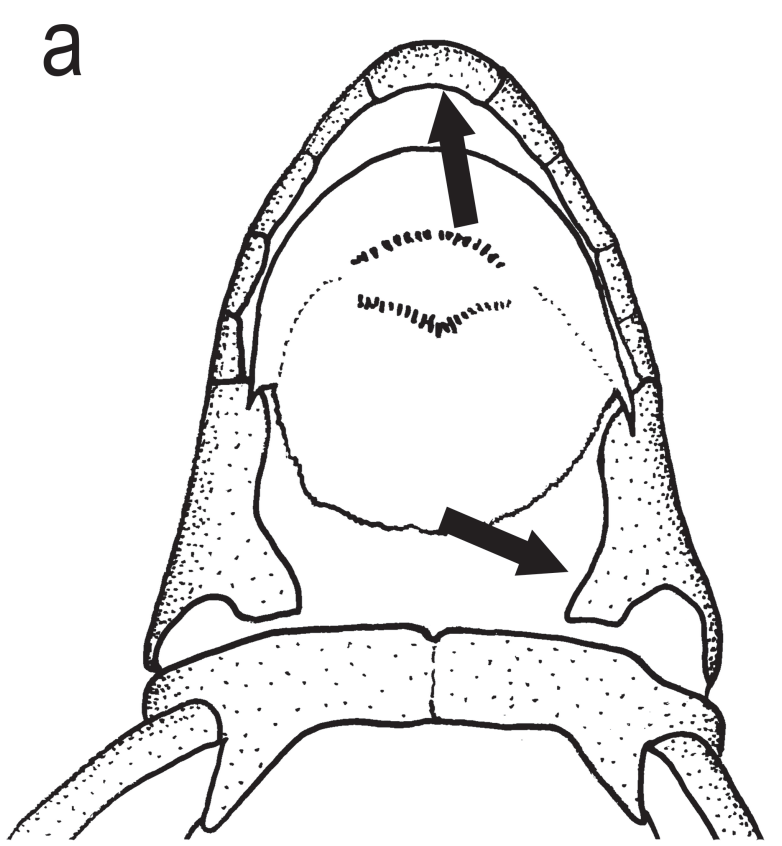

Shield and Amazon basin, namely Hisonotus acuen Silva, Roxo, Oliveira, 2014, whose cusps are golden yellow, $H$. chromodontus Britski, Garavello, 2007, which has reddish brown cusps, and the species of Parotocinclus from the Amazon, Orinoco and the Guianas.

Two additional morphological features are shared by Curculionichthys hera, C. jumaorum, Hisonotus acuen, $H$. bockmanni Carvalho, Datovo, 2012, H. chromodontus, and the aforementioned Parotocinclus species. Such features are a single, medial rostral plate (Fig. 6), contrary to all remaining Curculionichthys, which possess a pair of rostral plates (but some individuals of $C$. karipuna may have a single rostral plate according to its original description in Silva et al., 2016), and the ventral portion of the cheek canal plate turned posteriorly, with a lamina towards the pectoral girdle (Fig. 6 ; vs. ventral portion of the canal plate elongated mesially).

The above features possibly carry useful phylogenetic information and could represent synapomorphies of a distinct lineage that must be further tested in a phylogenetic framework. A clade containing Curculionichthys hera (treated as Curculionichthys sp.n.), Hisonotus acuen, $H$. bockmanni, H. chromodontus, and four species of Amazonian Parotocinclus has already been recovered in a combined molecular and morphological phylogenetic analysis of the Hypoptopomatinae by Reis et al. (2017), and the description of a new genus to reallocate this group is underway by two authors of that study (P. Lehmann and RER). More recently, Roxo et al. (2019), using ultraconserved elements in a genomic phylogeny of the loricariids, also found $H$. acuen, $H$. chromodontus, and two species of Amazonian Parotocinclus as a clade, which they termed "New Genus 2".

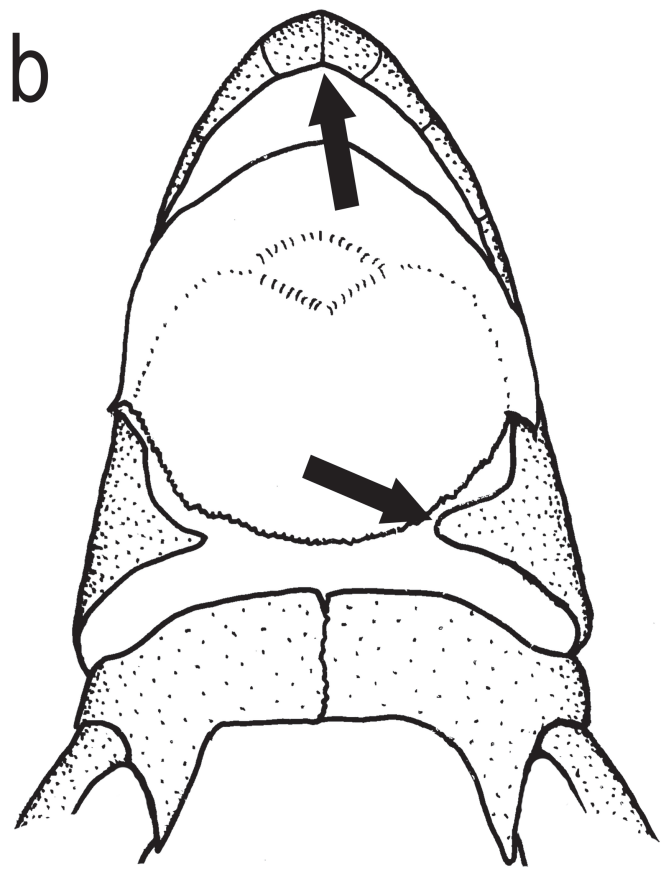

Fig. 6. Schematic drawing of the ventral side of head and pectoral girdle of Curculionichthys species. a. $C$. hera, arrows point posteriorly directed canal plate and single rostral plate; b. C. scaius, arrows point mesially directed canal plate and double rostral plate. 


\section{Acknowledgments}

We are grateful to Carlos Lucena and Margarete Lucena for continued assistance and support at MCP fish collection; to Carla Pavanelli (NUPELIA), Alessio Datovo and Michel Gianeti (MZUSP), and Barbara Brown and Scott Schaefer (AMNH) for curatorial assistance in their institution; to Tiago Carvalho, Juan de Bogotá, Cárlison Oliveira, Jordson Souza, and Elias Cerdeira for the sharing comradery and help during road fieldwork in Pará; to Juliano Romanzini for the assistance with stereomicroscope photographs of Fig. 3; and to the Central Laboratory of Microscopy and Microanalysis for the production of Fig. 2. The collection of fishes associated with this study was financed by the project Aquatic Faunal Survey of the Lower Amazon (National Science Foundation grant DEB-1146374 to William G. R. Crampton) and performed under ICMBio license \#377424 to RER. The authors are grateful to the Coordenação de Aperfeiçoamento de Pessoal de Nível Superior (CAPES, Postdoctoral fellowship, process \#88887.137808/201700 to $\mathrm{BBC}$ ), Pontifícia Universidade Católica do Rio Grande do Sul (PUCRS, undergraduate fellowship, Bolsas Pesquisa Alunos to SPG), and the Conselho Nacional de Desenvolvimento Científico e Tecnológico (CNPq process \# 306455/2014-5 to RER).

\section{References}

Calegari BB, Fontenelle JP. Tutorial de preparação de mapas de distribuição geográfica: Parte II - Mapa Hipsométrico. Bol Soc Bras Ictiol. 2017; (124):14-34.

Calegari BB, Gamarra SP, Reis RE. A new species of Curculionichthys (Siluriformes: Hypoptopomatinae) from the western border of the Brazilian Shield, Madeira River basin, Brazil. Copeia. 2018; 106(4):663-70.

Calegari BB, Lehmann P, Reis RE. A new species of Otothyropsis (Siluriformes: Loricariidae) from the río Paraguay basin, Paraguay. Neotrop Ichthyol. 2011; 9(2):253-60.

Calegari BB, Silva EV, Reis RE. Microlepidogaster discontenta, a new species of hypoptopomatine catfish (Teleostei: Loricariidae) from the rio São Francisco basin, Brazil. Ichthyol Explor Freshw. 2014; 25(3):213-21.

Carvalho TP, Reis RE. Four new species of Hisonotus (Siluriformes: Loricariidae) from the upper rio Uruguay, southeastern South America, with a review of the genus in the rio Uruguay basin. Zootaxa. 2009; 2113:1-40.

Chakrabarty P, Warren M, Page LM, Baldwin CC. GenSeq: An updated nomenclature and ranking for genetic sequences from type and non-type sources. ZooKeys. 2013; (346):29-14.

Dias AC, Silva GSC, Oliveira C, Roxo FF. A new species of Hisonotus (Siluriformes: Loricariidae) from Aripuanã river, Amazon basin, Brazil. Zootaxa. 2018; 4504:577-85.

Folmer O, Black M, Hoeh W, Lutz R, Vrijenhoek R. DNA primers for amplification of mitochondrial cytochrome $\mathrm{c}$ oxidase subunit I from diverse metazoan invertebrates. Mol Mar Biol Biotechnol. 1994; 3:294-99.
Fricke R, Eschmeyer WN, van der Laan R, editors. Catalog of fishes: Genera, species, references [Eletronic version]. San Francisco: California Academy of Science; 2019 [cited 2019 Mar 25]. Available from: http://researcharchive.calacademy. org/research/Ichthyology/catalog/fishcatmain.asp

International Union for Conservation of Nature (IUCN). Standards and Petitions Subcommittee. Guidelines for using the IUCN Red List Categories and Criteria. Version 13 [Internet]. 2017 [accessed May 2018]. Available from: http://www.iucnredlist. org/documents/RedListGuidelines.pdf

Reis RE, Calegari BB, Carvalho TP, Cramer CA, Delapieve MLS, Lehmann P, Pereira EHL. A phylogeny of the armored catfishes, with emphasis on the Neoplecostominae-Hypoptopomatinae clade (Siluriformes: Loricariidae): Integrating phenotypical and molecular data. Londrina: II International Symposium on Phylogeny and Classification of Neotropical Fishes; 2017.

Roxo FF, Dias AC, Silva GSC, Oliveira C. Two new species of Curculionichthys (Siluriformes: Loricariidae) from the rio Amazonas basin, Brazil. Zootaxa. 2017; 4341(2):258-70.

Roxo FF, Ochoa LE, Sabaj MH, Lujan NK, Covain R, Silva GSC, Melo BF, Albert JS, Chang J, Foresti F, Alfaro ME, Oliveira C. Phylogenomic reappraisal of the Neotropical catfish family Loricariidae (Teleostei: Siluriformes) using ultraconserved elements. Mol Phylogenet Evol. 2019; 135:148-65.

Roxo FF, Silva GSC, Ochoa LE, Oliveira C. Description of a new genus and three new species of Otothyrinae (Siluriformes, Loricariidae). Zookeys, 2015; 534:103-34.

Roxo FF, Zawadzki CH, Troy WP. Description of two new species of Hisonotus Eigenmann \& Eigenmann, 1889 (Ostariophysi, Loricariidae) from the rio Paraná-Paraguay basin, Brazil. ZooKeys. 2014; 395:57-78.

Sabaj MH. Standard symbolic codes for institutional resource collections in herpetology and ichthyology: an Online Reference. Version 6.5 [Internet]. 2016 [accessed 16 August 2016]. Available from: http://www.asih.org/, American Society of Ichthyologists and Herpetologists, Washington, DC.

Schaefer SA. The Neotropical cascudinhos: Systematics and biogeography of the Otocinclus catfishes (Siluriformes: Loricariidae). Proc Acad Nat Sci Philadelphia. 1997; 148:1-120.

Silva GSC, Roxo FF, Melo BF, Oliveira C. New species of Curculionichthys (Siluriformes: Loricariidae) from the eastern Guiana Shield. Zootaxa. 2016; 4175(3):281-91.

Taylor WR, van Dyke GC. Revised procedures for staining and clearing small fishes and other vertebrates for bone and cartilage study. Cybium. 1985; 9(2):107-19.

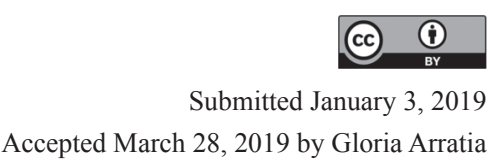

Submitted January 3, 2019 Accepted March 28, 2019 by Gloria Arratia 